\title{
Omentum Adiposity is Linked with Resistin Gene Expression
}

\section{Belgin Süsleyici-Duman ${ }^{1 *}$, Fatma Kaya Dağıstanlı², Meliha Koldemir-Gündüz', Halit Eren Taşkın³, Kağan Zengin ${ }^{3}$, Figen Esin Kayhan ${ }^{4}$,} Penbe Çağatay ${ }^{5}$, Mustafa Taşkın ${ }^{3}$ and Melek Öztürk ${ }^{2}$

${ }^{1}$ Marmara University, Faculty of Science and Arts, Biology Division, Department of Molecular Biology, Istanbul, Turkey

${ }^{2}$ Istanbul University, Cerrahpasa Medical Faculty, Department of Medical Biology, Istanbul, Turkey

${ }^{3}$ Istanbul University, Cerrahpasa Medical Faculty, Department of Surgery, Istanbul, Turkey

${ }^{4}$ Marmara University, Faculty of Science and Arts, Biology Division, Department of Zoology, Istanbul, Turkey

${ }^{5}$ Istanbul University Istanbul Medical Faculty, Department of Biostatistic and Medical Informatics, Istanbul, Turkey

\begin{abstract}
Background: This study demonstrated site-specific adipose tissue resistin gene expression differences in individuals with and without type 2 diabetes mellitus. The relationship between conventional drug therapy and adipose tissue resistin gene expression was also determined. Paired omental and subcutaneous adipose tissues were excised during elective surgery from morbidly obese and obese patients.
\end{abstract}

Methods: Resistin mRNA expressions were determined by qPCR. All tissue sections also were also analyzed for their resistin and CD68 protein expressions by immunohistochemistry.

Results: No significant difference for omental and subcutaneous adipose tissue resistin mRNA expression levels were found among morbidly obese and obese study groups. The omental adipocytes resistin mRNA expressions increased with macrophage number both in the omental and subcutaneus fat. Resistin mRNA expressions of the omental and subcutaneous fat were in positive correlation. As the omental adipocytes radius decreased, the macrophage number increased in subcutaneous fat. In the omentum the adipocytes diameter and areas increased, in correlation with macrophage number. The antidiabetic drug use was found to increase adipocyte size both in the omentum and subcutaneous fat.

Conclusions: The higher resistin gene expression in the omental fat may induce the increase in size and number of adipocytes, thus leading to elavation in omental fat mass.

Keywords: Resistin; CD68; Gene expression; Adipose tissue; Drug

Abbreviations: TG: Triglycerides; T2DM: Type 2 Diabetes Mellitus; BMI: Body Mass İndex; OM: Omental Adipose Tissue; SC: Subcutaneous Adipose Tissue; IDF: International Diabetes Federation; GUSB: $\beta$-Glucuronidase; TBP: TATA-Binding Protein; MO: Morbidly Obese; HbAlc: Glycated haemoglobin; AST: Aspartate Aminotransferase; ALT: Alanine Transaminase; TZDs: Thiazolidinone; RSG: Including Rosiglitazone

\section{Introduction}

Recent studies have shown the potential contribution of visceral adipose tissue, via it's secretory function, to the pathogenesis of obesity and related disease such as diabetes, hypertension, and cardiovascular disease. Adipocytes secrete adipokines, such as resistin [1]. In obesity fat cell size and cell number increases. Lipolysis in adipocytes results from breakdown of adipocyte triglycerides (TG) into nonesterified fatty acids and glycerol through the action of lipases and TG hydrolases $[2,3]$. Adipose tissue is a critical endocrine organ involved in regulating obesity, insulin resistance and type 2 diabetes mellitus (T2DM) [4,5]. Resistin is a circulating hormone, expressed primarily in adipocytes, known to antagonize insulin action in mice [6]. Resistin belongs to a family of secreted proteins (resistin like molecules) that share an unusual cysteine-rich motif at the amino terminal ending [7]. Janke et al. have reported higher expression of the resistin gene in human preadipocytes that decreased during adipogenic differentiation to very low levels [8]. Consequently, resistin expression was weakly detectable in mature human adipocytes. The expression of the resistin gene has been reported to be lower in the obese, diabetes, tubby, and viable yellow mouse models of genetically determined obesity, suggesting that formation of resistin may not be related to insulin resistance in these models [9]. The expression of the resistin gene in fat cells and adipose tissue from overweight subjects has been reported to be almost absent [10], making the question of the role of resistin in human obesity and diabetes controversial.
Resistin and some adipokines, such as TNF- $\alpha$ and IL- 6 are produced and secreted by both adipocytes and macrophages in T2DM $[6,11]$. Increased production of these adipokines occurs with particularly visceral obesity, by both the adipocytes and the nonfat cells, mostly macrophages that infiltrate the adipose tissue $[12,13]$. While resistin's role as an inflammatory marker in human and rodent physiology is well known, its role in obesity and T2DM is still under investigation. It is important to note that human resistin is expressed in much higher levels in macrophages than in adipocytes [14]. Several human studies have failed to show relationship of circulating resistin levels with Body Mass İndex (BMI) or other metabolic parameters $[8,15,16]$. In contrary, there are reports detecting increased serum resistin levels in obesity and/or type 2 diabetes [17-19]. It has been suggested by Nagaev et al. that oral antidiabetic treatment, namely thiazolidinedione greatly downregulated resistin gene expression, and neutralization of the resistin protein enhanced blood glucose uptake and insulin sensitivity [10]. The aim of this study was to evaluate the site-specific differences in adipose tissue resistin gene expression among individuals with and without T2DM. Conventional drug therapy relationships with adipose tissue resistin expression were also detected.

*Corresponding author: Belgin Süsleyici-Duman, Marmara University Faculty of Science and Arts, Division of Biology, Department of Molecular Biology, GöztepeIstanbul, Turkey, Tel: +90-216-3464553-1361; Fax: +90 21634787 83; E-mail: belgin.susleyici@marmara.edu.tr

Received May 24, 2013; Accepted June 10, 2013; Published June 22, 2013

Citation: Süsleyici-Duman B, Dağıstanlı FK, Koldemir-Gündüz M, Taşkın HE, Zengin K, et al. (2013) Omentum Adiposity is Linked with Resistin Gene Expression. Surgery Curr Res 3: 133. doi:10.4172/2161-1076.1000133

Copyright: (c) 2013 Süsleyici-Duman B, et al. This is an open-access article distributed under the terms of the Creative Commons Attribution License, which permits unrestricted use, distribution, and reproduction in any medium, provided the original author and source are credited. 


\section{Materials and Methods}

\section{Subjects and tissue sampling}

Omental adipose tissue $(\mathrm{OM})$ and subcutaneous adipose tissue (SC) biopsies were obtained from 10 morbidly obese patients (6 women, 4 men) and 5 overweight controls ( 2 women, 3 men) during elective surgery. The morbidly obese (age: $43.20 \pm 3.95)$ and overweight (age: $44.20 \pm 4.35$ ) study groups were matched for age and sex. Obesity and T2DM were diagnosed according to International Diabetes Federation (IDF) guidelines [20]. Among morbidly obese patients, $6(60 \%)$ were suffering from T2DM, 4 (40\%) from hypertension, 3 (30\%) from dyslipidemia and $6(60 \%)$ from metabolic syndrome. Subjects with cancer, collagen diseases, endocrinopathies, secondary hypertension (renal artery stenosis, glomerulonephritis), and diabetic microangiopathic complications were excluded from the study. The drug use for the morbidly obese subjects were: $40 \%$ for hypertensives, $60 \%$ for antidiabetics; $30 \%$ for antiobesity drugs. None of the overweight subjects were using any drugs. When the data of morbidly obese patients were analyzed, a great majority of the group was observed to have insulin resistance.

All the individuals in the study group gave their written informed consent, and the project was approved by the local ethics committee. All the fat tissues were collected during operation in the form of biopsy. One half of the tissue samples were immediately transferred into liquid nitrogen, and subsequently stored at $-80^{\circ} \mathrm{C}$ prior to total RNA isolation, the other part was fixed in $10 \%$ neutral buffered formaline for immunohistochemistry.

\section{Biochemical measurements}

All biochemical measurements were determined by using enzymatic reference methods.

\section{RNA isolation and real time PCR analysis}

The total RNA from $\mathrm{OM}$ and SC fat tissues were extracted with High Pure RNA Tissue Kit (Roche, Germany) according to the manufacturers instructions. Total RNA samples were diluted in DNase-RNase free sterile water and stored at $-80^{\circ} \mathrm{C}$ until use. Transcriptor HiFi cDNA synthesis kit was used for cDNA synthesis (Roche). Expression of resistin gene was determined by quantitative real-time PCR using a LightCycler 2.0 (Roche Diagnostics, Germany) instrument. Ten fold dilutions of cDNA synthesized from total RNA of normal weight individuals adipose tissue were used in each run, with their duplicates, in order to obtain standard curves of $\beta$-Glucuronidase (GUSB) and TATA-binding protein (TBP) amplification necessary for real-time quantification. Measurements were carried out on at least three occasions for each sample analyzed. Ct values of 40 were excluded from further mathematical calculations. The expression amounts were calculated by using the expression of both GUSB and TBP, which were used as a reference genes. Resistin mRNA was subsequently normalized to both GUSB and TBP mRNA levels. The presence of specific gene products were also confirmed with melting curve analysis. Primer sequences used were as follows: for Resistin (forward) 5'- TGG AAG AAG CCA TCA ATG AGA -3', (reverse) 5'- AAT GCT GCT TAT TGC CCT AAA T -3'; for GUSB (forward) 5'- CGC CCT GCC TAT CTG TAT TC- $3^{\prime}$, (reverse) $5^{\prime}$ - TCC CCA CAG GGA GTG TGT AG - $3^{\prime}$; for TBP (forward) 5'- GCT GGC CCA TAG TGA TCT TT - $3^{\prime}$ and (reverse) 5' - TCC TTG GGT TAT CTT CAC ACG - $3^{\prime}$. The resistin mRNA levels normalized to TBP has been used in the statistical analysis.

\section{Immunohistochemistry staining for resistin and CD68}

Resistin and macrophage specific CD68 imunohistochemical staining were performed by streptavidin-biotin-peroxidase method on $10 \%$ neutral buffered formalin-fixed, paraffin embedded adipose tissue specimens. The sections of $4 \mu \mathrm{m}$ thickness were placed onto slides coated with poly-L-Lysine, (PLL, Sigma, St. Louis, MO) then deparaffinized in xylene and rehydrated in graded alcohol. Histostain Plus Bulk Kit (Zymed; USA) was used for immunoperoxidase staining. Immunohistochemistry procedure was performed using a combination of microwave oven heating for antigen retrieval and standard streptavidin-biotin-peroxidase method. Endogenous peroxidase activity was blocked by hydrogen peroxide (3\%). Each section was then incubated for 15 minutes at room temperature with blocking solution. Sections were incubated with resistin (dilution 1:100; Santa Cruz Biotechnology, Santa Cruz, CA, USA) or CD68 (prediluted; LabVision Corp., USA) for 1 hour at room temperature, then washed with PBS. Specific staining was performed with biotinlated universal secondary antibody, horseradish peroxidase streptavidin-complex, and aminoethyl-carbazole as chromogen. As for negative control, distilled water was performed instead of primary antibody.

\section{Morphometric analysis}

Morphometric analysis for CD68 positive cells was performed for sections, using a light microscope. Automatic image analysis of sections for calculation of tissue areas was performed with Leica IM50 (version4.0) morphometric analysis software (Leica, Germany). Cell counts were performed using a x20 objective in 10 different fields. Resistin immunoreactivity was evaluated semiquantitavely according to the staining intensity.

\begin{tabular}{|c|c|c|c|}
\hline & Morbid Obese $(n=10)$ & Obese $(n=5)$ & $p$ \\
\hline BMI $\left(\mathbf{k g} / \mathbf{m}^{2}\right)$ & $47.4 \pm 3.14 ; 42.4(40-72)$ & $28.61 \pm 1.27 ; 27.7(26-33)$ & $0.0001^{*}$ \\
\hline Fasting glucose $(\mathrm{mg} / \mathrm{dl})$ & $139.40 \pm 24.22 ; 112.0(78-326)$ & $101.2 \pm 7.13 ; 105.0(78-121)$ & 0.594 \\
\hline HbA1c (\%) & $6.83 \pm 0.84 ; 6.0(5-13)$ & $5.08 \pm 0.17 ; 5.10(5-6)$ & 0.129 \\
\hline AST (U/L) & $48.00 \pm 20.86 ; 24.0(14-209)$ & $35.00 \pm 12.83 ; 17(13-75)$ & 0.518 \\
\hline ALT (U/L) & $55.67 \pm 16.51 ; 34.0(16-160)$ & $38.60 \pm 16.01 ; 19(7-90)$ & 0.364 \\
\hline Hematocrit (\%) & $40.03 \pm 2.07 ; 39.8(32-48)$ & $38.36 \pm 3.67 ; 38.4(24-49)$ & 0.792 \\
\hline Free T3 (pmol/L) & $3.16 \pm 0.11 ; 3.23(2.7-3.5)$ & $3.19 \pm 0.12 ; 3.05(2.9-3.2)$ & 0.124 \\
\hline Free T4 (ng/dl) & $1.02 \pm 0.06 ; 1.0(0.8-1.2)$ & $1.00 \pm 0.07 ; 1.10(0.9-1.3)$ & 0.119 \\
\hline TSH $(\mu \mathrm{lU} / \mathrm{mL})$ & $4.31 \pm 1.05 ; 3.3(3.0-10.6)$ & $4.01 \pm 1.03 ; 3.0(2.75-8.9)$ & 0.234 \\
\hline
\end{tabular}

$\mid$ Morbid obese: $\mathrm{BM} \mid \geq 40$, Obese: $\mathrm{BM} \mid \geq 25$. Values are represented as mean $\pm \mathrm{SE}$

BMI: Body mass index. HbA1c: Glycated haemoglobin. AST: Aspartate aminotransferase. ALT: Alanine transaminase

TSH: Thyroid-stimulating hormone. $p<0.001$

Table 1: The demographic and biochemical characteristics of the obese groups. 


\section{Semiquantitation of immunoperoxidase staining}

Immunostaining was evaluated using a LeicaDM2500 light microscope (LeicaMicrosystems, Wetzlar,Germany). Resistin staining was evaluated in 10 randomly selected all fields of tissue sections using a x20 objective. The immunostaining of cells was scored as: no staining $(-)$, weak staining $(+)$, moderate staining $(++)$ and strong staining $(+++)$.

\section{Statistical analysis}

Data are expressed as numbers and percentages for discrete variables and as mean $\pm \mathrm{SE}$, for continuous variables. Baseline differences between study groups were examined by Mann-Whitney $U$ test. Variables were analyzed by Spearman's correlation test using SPSS 17.0 (SPSS Inc., Chicago, IL, USA) for windows. Statistical significance was taken as $\mathrm{p}<0.05$.

\section{Results}

\section{Basic subject characterization}

The demographic and biochemical characteristics of the study groups as a fuction of obesity are shown in Table 1. Fasting glucose, glycated haemoglobin $(\mathrm{HbAlc})$, aspartate aminotransferase (AST), alanine transaminase (ALT), hematocrit, Free T3, Free T4 and thyroid stimulating hormone (TSH) levels were not statistically different in the morbidly obese (MO) and obese study groups. BMI was higher in morbidly obese patients than that of overweight patients $(\mathrm{p}<0.001)$.

\section{Immunohistochemistry results}

In morbidly obese group resistin immunopositivity was observed to be more intense in adipocytes cytoplasm and also non-fatty cells in intracellular area of the omental and subcutaneous tissues in comparison to the obese group (Figure 1 and Table 2). The omental resistin immunopositivity was more intense in the intercellular area in the morbidly obese compared to obese group (Figure 1 and Table 2). No immune reaction was observed in negative controls.

The macrophage specific CD68 immunopositive cells were observed in the intercellular area (Figure 2). The CD68 immunopositive macrophage number was found to be higher in morbidly obese group compared to obese both in omental and subcutaneous fat tissues significantly. In morbidly obese group, especially in the omentum, the CD68 immunopositive macrophage number was higher to that of subcutaneous fat tissue (Figure 2 and Table 3 ).

\section{Resistin gene expression in omental adipose and subcutaneous adipose tissues}

The resistin expression rates in omental and subcutaneous adipose tissues by using TBP as reference gene are given in Table 4. In detail, omental and subcutaneous adipose tissue resistin expression levels were not found to differ significantly among morbidly obese and obese study groups. The omental and subcutaneous resistin expression rates were not found to differ significantly in morbidly obese and obese grups. The morbidly obese patients omental fat adipocytes $(0.290 \pm 0.220)$ were found to have higher resistin expression rates in comparison to subcutaneous adipocytes $(0.060 \pm 0.050)$, where expression was nearly absent. Resistin gene expression was absent in omental and subcutaneous adipocytes of obese patients (Table 4).

The resistin gene and CD68 positive macrophage number correlations both in omentum and subcutaneous fat were evaluated. The omental adipocytes resistin expressions were found to increase

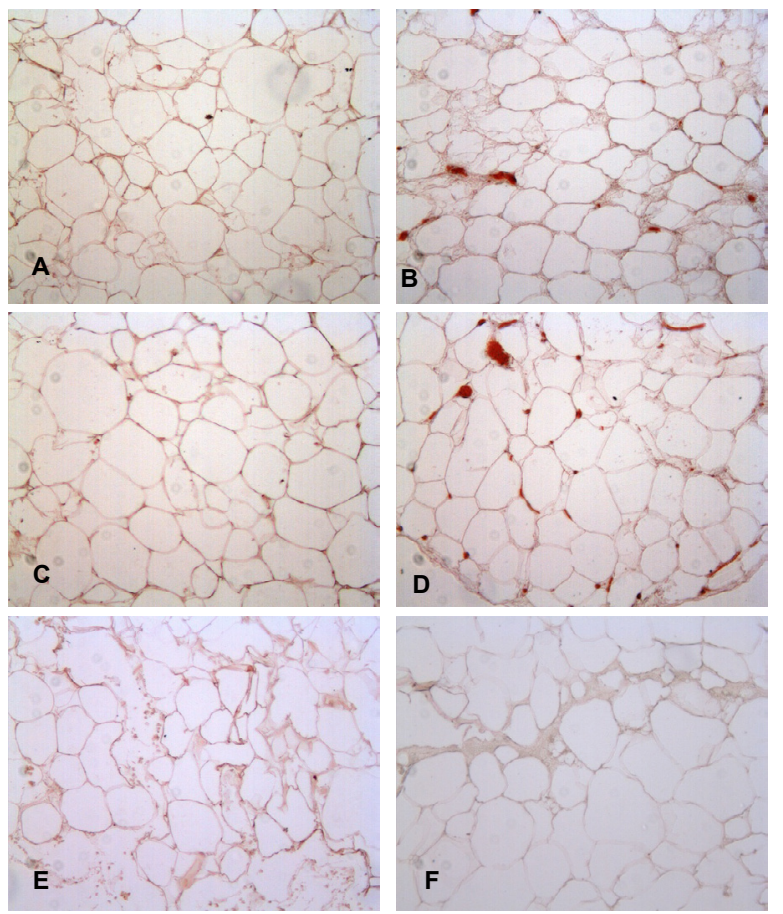

Figure 1: Resistin immunopositive fat cells and non fat cells are seen in subcutaneous (A) and omental (B) adipose tissues of obese group, and in subcutaneous $(C)$ and omental $(D, E)$ adipose tissues of morbid obese group.

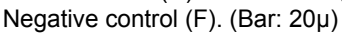

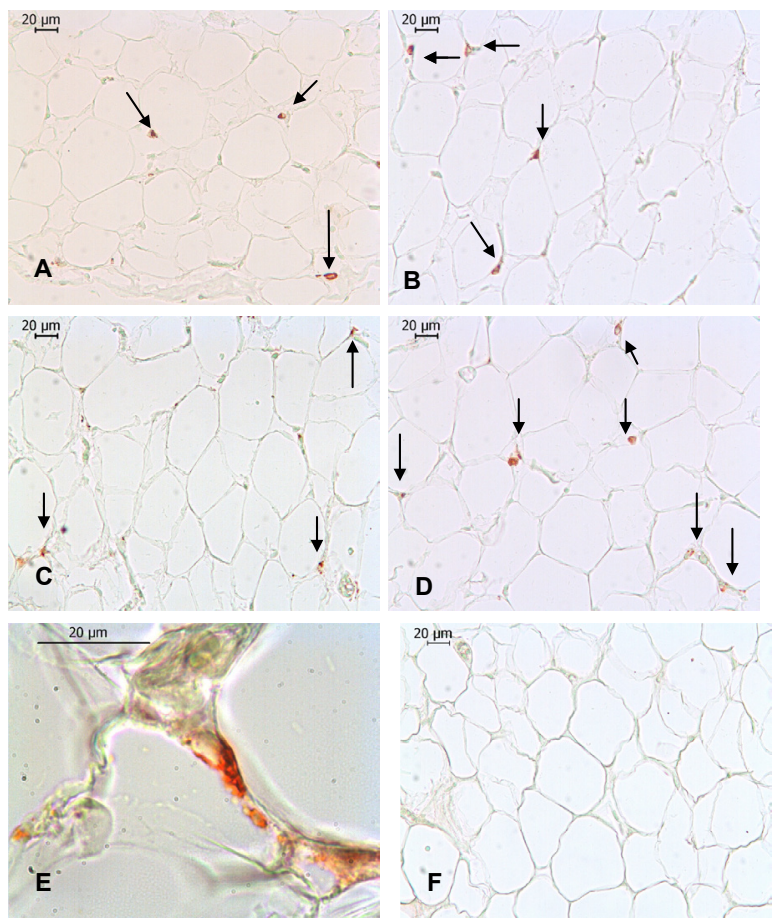

Figure 2: CD68 immunopositive cells are seen in subcutaneous adipose tissue of obese $(A)$ and morbid obese $(B)$ and also in omental adipose tissue of obese group (C). CD68 labbelled cells $(\uparrow)$ between degenerated fat cells $(D)$ and enlarged fat cells $\left(^{*}\right)(E)$ are seen in the omentum of the morbid obese. The omentum of morbid obese group $(F)(\boldsymbol{\Delta})$ has more CD68 positive cells

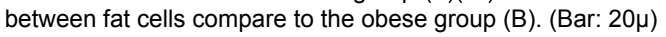




\begin{tabular}{|l|c|c|c|}
\hline & Morbid Obese $\mathbf{( n = 1 0 )}$ & Obese $(\mathbf{n}=\mathbf{5})$ & $\mathbf{p}$ \\
\hline Subcutaneous CD68 expression & $5.70 \pm 0.23$ & $0.50 \pm 0.10$ & 0.2 \\
\hline Omental CD68 expression & $10.60 \pm 0.38$ & $0.50 \pm 0.10$ & 0.4 \\
\hline
\end{tabular}

Morbid obese: $\mathrm{BMI} \geq 40$, Obese: $\mathrm{BMI} \geq 25$. Values are represented as mean $\pm \mathrm{SE}$

Table 2: CD68 immunopositive cell numbers in omental and subcutaneous fat tissue.

\begin{tabular}{|l|c|c|c|c|}
\hline \multirow{2}{*}{} & \multicolumn{3}{|c|}{ MO } & \multicolumn{2}{c|}{ OB } \\
\cline { 2 - 5 } & SC & OM & SC & OM \\
\hline Adipocyte & ++ & ++ & + & + \\
\hline Intercellular area & ++ & +++ & + & ++ \\
\hline
\end{tabular}

MO: Morbid Obese. OB: Obese. SC: Subcutaneous fat tissue. OM: Omental fat tissue

Immunoreactivity of cells is scored as: no staining $(-)$, weak staining $(+)$, moderate staining $(++)$ and strong staining $(+++)$

Table 3: Resistin immunoreactivity in fat tissue sections of all groups.

\begin{tabular}{|l|c|c|}
\hline & Resistin TBP Omentum $_{\mathrm{ER}}$ & Resistin TBP Subcutaneous $_{\mathrm{ER}}$ \\
\hline Morbid Obese & $0.290 \pm 0.220$ & $0.060 \pm 0.050$ \\
\hline Obese & Zero expression & Zero expression \\
\hline
\end{tabular}

Results are expressed as mean \pm SE. TBP: TATA-binding protein. ER: Resistin gene expression rate. $p>0.05$

Table 4: The resistin gene expression rates in omental and subcutaneous adipose tissues.

\begin{tabular}{|l|c|c|c|c|}
\hline & \multicolumn{2}{|c|}{ Omental (TBP) } & \multicolumn{2}{c|}{ Subcutaneous (TBP) } \\
\hline & $r_{s}$ & $p$ & $r_{s}$ & $p$ \\
\hline Subcutaneous CD68 & 0.880 & $0.021^{*}$ & 0.783 & 0.118 \\
\hline Omental CD68 & 0.820 & $0.046^{*}$ & 0.671 & 0.215 \\
\hline
\end{tabular}

TBP: TATA-binding protein

The values are represented as Spearman's corralation coefficient $\left(r_{\mathrm{s}}\right)$ and statistical $(p)$ significance * $p<0.05$

Table 5: Correlation coefficients of resistin gene expression rates and macrophage CD68 in omental and subcutaneous fat tissues.

with macrophage marker CD68 amount both in the omentum $\left(r_{s}=0.820, p=0.046\right)$ and subcutaneus fat $\left(r_{s}=0.880, p=0.021\right)$ (Table 5).

The correlation between drug use and CD68 immunopositive macrophage number with adipocyte morphometric parameters are given in Table 6. As the omental adipocytes radius measurements have decreased, the macrophage specific CD68 immunopositive macrophage number increased in subcutaneous fat ( $\mathrm{rs}=-0.845$, $\mathrm{p}=0.034$ ). As the adipocytes diameter and the area they occupy enlarge, the CD68 positive macrophage number also raises in the omentum $\left(r_{s}=0.829, p=0.042\right)$. The antidiabetic drug use was found to change the morphometric characteristics of adipocytes both in the omental (adipocyte diameter, area) and subcutaneous fat tissues (adipocyte diameter, area and radius) $\left(\mathrm{r}_{\mathrm{s}}=0.878, \mathrm{p}=0.021\right)$. Antihypertensive and antiobesity drugs were found to be ineffective on adipocytes morphometric parameters (Table 6).

\section{Discussion}

Metabolic disorders are closely associated with increased visceral adiposity. The gene expression profile for visceral adipose tissue may serve as a useful reference for future pathophysiological studies involving this tissue [20]. Even a slight weight loss in morbidly obese patients have shown rapid improvement within the vital data, which is also the reason for us to select obese patients instead of non-obese ones to compare with morbidly obese patients. Janke et al. found higher resistin gene expression in human preadipocytes which decreased during adipogenic differentiation to very low levels. Consequently, resistin gene expression was hardly detectable in mature human adipocytes [8]. In our study, the measured resistin gene expressions we considerably low in type 2 diabetic and morbidly obese patients fat tissues. Our gene expression results were consistent with immunohistochemical results obtained for morbidly obese fat tissues. No resistin gene expression was found in our obese patients subcutaneous or omental fat tissues, whereas weak resistin immunopositivity was found in both sites. The inconsistency of the gene and protein expression data in our obese group may be due to the undetectable low expression of resistin gene below the cut-off values.

It is well established that thiazolidinone (TZDs), including rosiglitazone (RSG), function as potent insulin-sensitizing agent by raising insulin-dependent glucose uptake and reducing hepatic glucose output [20-24]. Steppan et al. have also shown that TZD reduced resistin gene expression in 3T3-L1 adipocytes and adipose tissue in vivo [6]. In agreement to the results of McTernan et al. obtained from a rodent model [25], our data indicate that, resistin secretion from SC abdominal adipocytes increases under hyperinsulinemic conditions, and this rise may be as a result of oral antidiabetic drug use. The findings of Patel et al. verifying that resistin expression and secretion in human macrophages in vitro together with the identification of a putative peroxisome proliferator-activated receptor-binding site in the promoter of the resistin gene strongly support the idea that the resistin gene can be directly transcriptionally regulated by the peroxisome proliferator activated receptor-mediated mechanism [14]. In the present study, together with the decrease of omental adipocytes radius measurements, the CD68 positive macrophage number increased in subcutaneous fat. As the adipocytes diameter and area increased, the CD68 positive macrophage number also raised in our samples omental fat tissues. The oral antidiabetic drug use was found to enlarge adipocyte size, both in the omental and subcutaneous fat tissues. The greater size and number of adipocytes observed in the antidiabetic drug or external insulin users in our study may demonstrate that, these type of drug use leads to weight gain during diabetes treatment. This observation is the major finding on pharmacogenomic results of our study.

In rodent models in vivo and in the murine 3T3-L1 adipose cell line, Lazar and co-workers demonstrated that recombinant resistin reduced glucose uptake [6]. In addition, obesity and insulin resistance are known to be associated with a chronic mild inflammation as determined by increased plasma C-reactive protein, IL-6, IL-8, and TNF levels in patients and different animal models of obesity $[26,27]$. This systemic inflammatory response is located in adipose tissue [28]. Inflammatory adipokine expression has been reported to be increased in obesity in mice [29-31] and humans [32]. To determine whether resistin exerts similar effects in human tissue, we examined the effects of human resistin on glucose and metabolic diseases in human omental and subcutaneous adipose tissues. According to our results, the degree of obesity was found to decrease with increased resistin gene expression in the omental fat tissue.

Since adipocytes have special roles in systemic insulin sensitivity [33], it is possible that inflammatory cytokines may trigger T2DM. Because inflammatory adipokines are mostly produced in obese adipose tissue, predominantly by nonfat cells such as macrophages adipose tissue macrophages are assumed to contribute to the pathogenesis of T2DM and thus the metabolic syndrome $[12,31]$. This suggestion is 


\begin{tabular}{|l|c|c|c|c|}
\hline & Antihypertensie & Antidiabetic & Antiobesity & Subcutaneous CD68 \\
\hline Diameter $_{\text {, }} \mu \mathrm{m}$ & $0.655,0.158$ & $0.878,0.021^{*}$ & $0.393,0.441$ & $0.657,0.156$ \\
\hline Radius $_{\mathrm{s},} \mu \mathrm{m}$ & $0.655,0.158$ & $0.488,0.326$ & $-0.131,0.805$ & $0.486,0.329$ \\
\hline Area $_{\mathrm{s},} \mathrm{mm}^{2}$ & $0.655,0.158$ & $0.878,0.021^{*}$ & $0.393,0.441$ & $0.600,0.208$ \\
\hline Diameter $_{\mathrm{o}} \mu \mathrm{m}$ & $0.131,0.805$ & $0.878,0.021^{*}$ & $0.393,0.441$ & $0.714,0.111$ \\
\hline Radius $_{\mathrm{o}} \mu \mathrm{m}$ & $-0.310,0.550$ & $-0.693,0.127$ & $-0.310,0.550$ & $0.771,0.072$ \\
\hline Area $_{\mathrm{o}}, \mu \mathrm{m}$ & $0.131,0.805$ & $0.878,0.021^{*}$ & $0.393,0.441$ & $-0.845,0.034^{*}$ \\
\hline
\end{tabular}

Values are expressed as Spearman's corralation coefficient $\left(r_{\mathrm{s}}\right)$ and statistical $(p)$ significance. ${ }^{*} p<0.05$

S: Subcutaneous fat cell. O: Omental fat cell

Table 6: The correlation between drug use and CD68 expression with adipocyte morphometric parameters.

supported by findings that obesity related adipose tissue inflammation is characterized by an increment of adipose tissue macrophages. In our study we detected significant increase in omental macrophages and resistin protein in morbidly obese patients fat tissues.

\section{Conclusion}

According to our results, the degree of obesity has been observed to change parametrically as a response to resistin gene expression in the omental fat. Therefore, by benefiting from this relationship in our future studies alternative drugs or gene therapy might be a chance for improvement of morbid obesity.

\section{Acknowledgement}

This project has been supported by İstanbul University Research Fund with BYP-1280 project number

\section{References}

1. Kim S, Moustaid-Moussa N (2000) Secretory, endocrine and autocrine/ paracrine function of the adipocyte. J Nutr 130: 3110S-3115S

2. Tansey JT, Sztalryd C, Gruia-Gray J, Roush DL, Zee JV, et al. (2001) Perilipin ablation results in a lean mouse with aberrant adipocyte lipolysis, enhanced leptin production, and resistance to diet-induced obesity. Proc Natl Acad Sci USA 98: 6494-6499.

3. Tansey JT, Sztalryd C, Hlavin EM, Kimmel AR, Londos C (2004) The central role of perilipin a in lipid metabolism and adipocyte lipolysis. IUBMB Life 56: 379-385.

4. Du J, Chen Q, Takemori $\mathrm{H}, \mathrm{Xu} \mathrm{H}$ (2008) SIK2 can be activated by deprivation of nutrition and it inhibits expression of lipogenic genes in adipocytes. Obesity (Silver Spring) 16: 531-538.

5. Gregoire FM (2001) Adipocyte differentiation: from fibroblast to endocrine cell. Exp Biol Med (Maywood) 226: 997-1002.

6. Steppan CM, Bailey ST, Bhat S, Brown EJ, Banerjee RR, et al. (2001) The hormone resistin links obesity to diabetes. Nature 409: 307-312.

7. Steppan CM, Brown EJ, Wright CM, Bhat S, Banerjee RR, et al. (2001) A family of tissue-specific resistin-like molecules. Proc Natl Acad Sci USA 98: 502-506.

8. Janke J, Engeli S, Gorzelniak K, Luft FC, Sharma AM (2002) Resistin gene expression in human adipocytes is not related to insulin resistance. Obes Res 10: 1-5.

9. Way JM, Görgün CZ, Tong Q, Uysal KT, Brown KK, et al. (2001) Adipose tissue resistin expression is severely suppressed in obesity and stimulated by peroxisome proliferator-activated receptor gamma agonists. J Biol Chem 276 25651-25653.

10. Nagaev I, Smith $U$ (2001) Insulin resistance and type 2 diabetes are not related to resistin expression in human fat cells or skeletal muscle. Biochem Biophys Res Commun 285: 561-564.

11. Tilg H, Moschen AR (2006) Adipocytokines: mediators linking adipose tissue, inflammation and immunity. Nat Rev Immunol 6: 772-783

12. Fain JN (2006) Release of interleukins and other inflammatory cytokines by human adipose tissue is enhanced in obesity and primarily due to the nonfat cells. Vitam Horm 74: 443-477.

13. Bouloumié A, Curat CA, Sengenès C, Lolmède K, Miranville A, et al. (2005) Role of macrophage tissue infiltration in metabolic diseases. Curr Opin Clin Nutr Metab Care 8: 347-354.
14. Patel L, Buckels AC, Kinghorn IJ, Murdock PR, Holbrook JD, et al. (2003) Resistin is expressed in human macrophages and directly regulated by PPAR gamma activators. Biochem Biophys Res Commun 300: 472-476.

15. Lee JH, Chan JL, Yiannakouris N, Kontogianni M, Estrada E, et al. (2003) Circulating resistin levels are not associated with obesity or insulin resistance in humans and are not regulated by fasting or leptin administration: crosssectional and interventional studies in normal, insulin-resistant, and diabetic subjects. J Clin Endocrinol Metab 88: 4848-4856.

16. Utzschneider KM, Carr DB, Tong J, Wallace TM, Hull RL, et al. (2005) Resistin is not associated with insulin sensitivity or the metabolic syndrome in humans. Diabetologia 48: 2330-2333.

17. Degawa-Yamauchi M, Bovenkerk JE, Juliar BE, Watson W, Kerr K, et al. (2003) Serum resistin (FIZZ3) protein is increased in obese humans. J Clin Endocrinol Metab 88: 5452-5455.

18. Youn BS, Yu KY, Park HJ, Lee NS, Min SS, et al. (2004) Plasma resistin concentrations measured by enzyme-linked immunosorbent assay using a newly developed monoclonal antibody are elevated in individuals with type 2 diabetes mellitus. J Clin Endocrinol Metab 89: 150-156.

19. Tokuyama Y, Osawa H, Ishizuka T, Onuma H, Matsui K, et al. (2007) Serum resistin level is associated with insulin sensitivity in Japanese patients with type 2 diabetes mellitus. Metabolism 56: 693-698.

20. Yang YS, Song HD, Li RY, Zhou LB, Zhu ZD, et al. (2003) The gene expression profiling of human visceral adipose tissue and its secretory functions. Biochem Biophys Res Commun 300: 839-846.

21. Balfour JA, Plosker GL (1999) Rosiglitazone. Drugs 57: 921-930.

22. Olefsky JM (2000) Treatment of insulin resistance with peroxisome proliferatoractivated receptor gamma agonists. J Clin Invest 106: 467-472.

23. Hotta K, Funahashi T, Bodkin NL, Ortmeyer HK, Arita Y, et al. (2001) Circulating concentrations of the adipocyte protein adiponectin are decreased in paralle with reduced insulin sensitivity during the progression to type 2 diabetes in rhesus monkeys. Diabetes 50: 1126-1133.

24. Saltiel AR, Olefsky JM (1996) Thiazolidinediones in the treatment of insulin resistance and type II diabetes. Diabetes 45: 1661-1669.

25. McTernan PG, Fisher FM, Valsamakis G, Chetty R, Harte A, et al. (2003) Resistin and type 2 diabetes: regulation of resistin expression by insulin and rosiglitazone and the effects of recombinant resistin on lipid and glucose metabolism in human differentiated adipocytes. J Clin Endocrinol Metab 88 6098-6106.

26. Kahn SE, Zinman B, Haffner SM, O’Neill MC, Kravitz BG, et al. (2006) Obesity is a major determinant of the association of $\mathrm{C}$-reactive protein levels and the metabolic syndrome in type 2 diabetes. Diabetes 55: 2357-2364.

27. Kim CS, Park HS, Kawada T, Kim JH, Lim D, et al. (2006) Circulating levels of MCP-1 and IL-8 are elevated in human obese subjects and associated with obesity-related parameters. Int J Obes (Lond) 30: 1347-1355.

28. Hotamisligil GS, Shargill NS, Spiegelman BM (1993) Adipose expression of tumor necrosis factor-alpha: direct role in obesity-linked insulin resistance. Science 259: 87-91.

29. Moraes RC, Blondet A, Birkenkamp-Demtroeder K, Tirard J, Orntoft TF, et al. Study of the alteration of gene expression in adipose tissue of diet-induced obese mice by microarray and reverse transcriptionpolymerase chain reaction analyses. Endocrinology 144: 4773-4782.

30. Xu H, Barnes GT, Yang Q, Tan G, Yang D, et al. (2003) Chronic inflammation in fat plays a crucial role in the development of obesity-related insulin resistance. J Clin Invest 112: 1821-1830. 
Citation: Süsleyici-Duman B, Dağıstanlı FK, Koldemir-Gündüz M, Taşkın HE, Zengin K, et al. (2013) Omentum Adiposity is Linked with Resistin Gene Expression. Surgery Curr Res 3: 133. doi:10.4172/2161-1076.1000133

Page 6 of 6

31. Weisberg SP, McCann D, Desai M, Rosenbaum M, Leibel RL, et al. (2003) Obesity is associated with macrophage accumulation in adipose tissue. $\mathrm{J}$ Clin Invest 112: 1796-1808.

32. Clément K, Viguerie N, Poitou C, Carette C, Pelloux V, et al. (2004) Weight loss regulates inflammation-related genes in white adipose tissue of obese subjects. FASEB J 18: 1657-1669.

33. Kahn BB, Flier JS (2000) Obesity and insulin resistance. J Clin Invest 106 473-481. 